\title{
PENGARUH PEMUPUKAN NITROGEN TERHADAP PRODUKSI DAN KUALITAS HIJAUAN KACANG KORO PEDANG (Canavalia gladiata)
}

\section{The Effect of Nitrogen Fertilization on the Production and Quality of Sword Bean Forage (Canavalia gladiata)}

\author{
Maulidiah Lutfiani Safira, Henry Adhi Kurniawan, Ana Rochana, Nyimas Popi Indriani
}

Fakultas Peternakan Universitas Padjadjaran, Sumedang Jawa Barat, Indonesia

Kampus Jatinangor, Jalan Raya Bandung-Sumedang KM. 21

Sumedang 45363, Jawa Barat

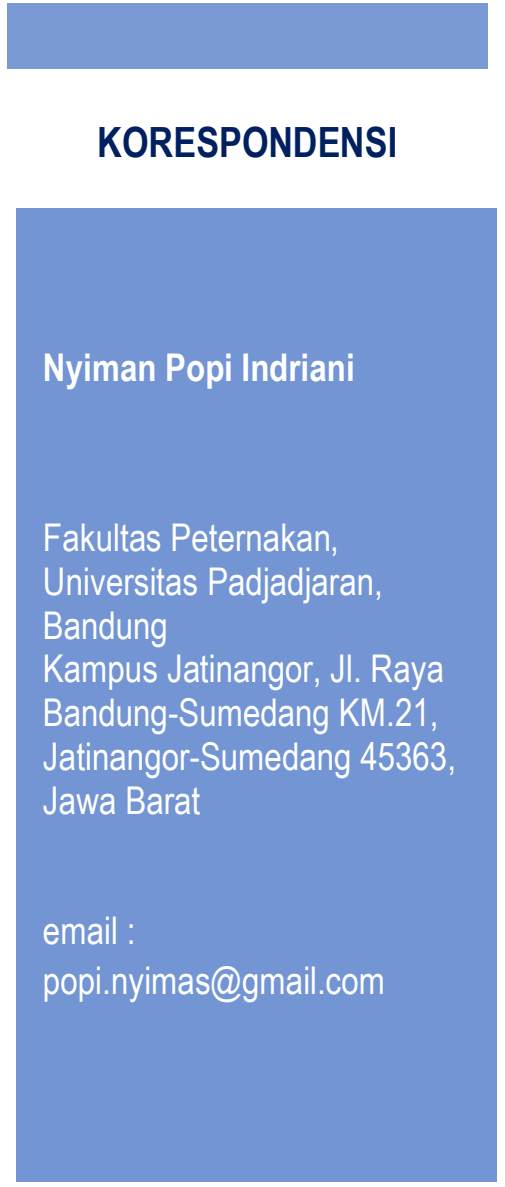

\begin{abstract}
ABSTRAK
Penelitian produksi dan kualitas hijauan pakan tanaman legum koro pedang (Canavalia gladiata) dengan pemberian berbagai dosis pupuk urea, telah dilaksanakan di Laboratorium Tanaman Makanan Ternak dan Laboratorium Nutrisi Ternak Ruminansia dan Kimia Makanan Ternak Fakultas Peternakan Universitas Padjadjaran. Tujuan dari penelitian ini adalah untuk mengetahui pengaruh pemupukan dosis urea terhadap produksi dan kualitas hijauan tanaman koro pedang dan juga mengetahui dosis pupuk urea terhadap produksi dan kualitas hijauan tanaman koro pedang. Penelitian menggunakan metode eksperimental dan Rancangan Acak Lengkap (RAL) dengan 5 perlakuan dan 4 kali pengulangan. Perlakuan yang dilakukan adalah pemupukan urea dengan dosis $0,50,100,150$, dan $200 \mathrm{~kg} / \mathrm{ha}$. Peubah yang diamati meliputi produksi (berat segar dan berat kering) dan kualitas (Protein kasar dan Serat Kasar) hijauan tanaman koro pedang. Data yang diperoleh dianalisis menggunakan sidik ragam dan uji jarak berganda Duncan. Hasil penelitian menunjukan bahwa pemberian berbagai dosis pupuk urea pada koro pedang memberikan hasil produksi yang sama tetapi kandungan protein kasar dan serat kasar berbeda. Pemupukan $50 \mathrm{~kg} / \mathrm{ha}$ pada koro pedang telah memenuhi syarat sumber hijauan ruminansia dengan
\end{abstract} kandungan protein kasar sebesar 27,13\%, kandungan serat kasar 20,56\%, hemat pupuk urea, rhizobium dapat bekerja maksimal, kesuburan tanaman koro pedang dan tanah tetap terjaga.

Kata kunci: urea; koro pedang; kualitas 


\section{ABSTRACT}

Research on the production and forage quality of sword bean legume (Canavalia gladiata) by providing various doses of urea fertilizer, has been carried out at the Laboratory of Animal Food Plants and Ruminant Nutrition and Animal Food Chemistry Laboratory of Animal Husbandry Faculty of Padjadjaran University. The purpose of this study was to determine the effect of fertilizing doses of urea on the production and forage quality of the sword bean plant and also to find out the dose of urea fertilizer on the production and forage quality of the sword bean plant. The study used an experimental method and a completely randomized design (CRD) with 5 treatments and 4 repetitions. The treatments taken were fertilizing urea at doses of 0,50,100, 150, and $200 \mathrm{~kg} / \mathrm{ha}$. Variables observed included production (fresh weight and dry weight) and quality (crude protein and crude fiber) forage of the sword bean. The data obtained were analyzed using variance analysis and Duncan's multiple range test. The results showed that the applications of various doses of urea fertilizer to sword bean gave the same production results but the contents of crude protein and crude fiber were different. Fertilization of $50 \mathrm{~kg} / \mathrm{ha}$ in sword bean fulfilled the requirements of ruminant forage sources with crude protein content of $27.13 \%$, crude fiber content of $20.56 \%$, saving urea fertilizer and the rhizobium working optimally. The fertility of sword bean plants and soil were maintained.

Keywords: urea; sword bean; production

\section{PENDAHULUAN}

Hijauan adalah bahan pakan utama ruminansia yang diperoleh dari rumput, legum dan tanaman lainnya yang harus tersedia sepanjang tahun dengan memperhatikan kualitas (kandungan zat-zat makanan) dan kuantitas. Salah satu legum yang berpotensi dalam memenuhi kebutuhan nutrien bagi ternak ruminansia adalah koro pedang (Canavalia gladiata). Koro pedang merupakan salah satu palawija yang berasal dari Asia atau Afrika yang ditanam secara luas di Asia Selatan dan Asia Tenggara, terutama di India, Srilanka, Myanmar, dan Indo-China. Kini koro pedang telah tersebar di seluruh daerah tropis dan telah beradaptasi di beberapa daerah termasuk Indonesia.

Hasil dari studi taksonomi genus canavalia di Afrika Selatan adalah genus tersebut termasuk dalam suku diocleae yang baru saja ditinjau ulang (sebelumnya subsuku diocleinae). Canavalia saat ini dibagi menjadi subgenus: Canavalia, Catodonia, Maunaloa dan Wenderothia. Ada 4 spesies dari subgenus Canavalia di Afrika selatan yaitu C. africana, C. ensiformis, $C$, gladiata, dan $C$ rosea. Canavalia subgenus Catodonia adalah subgenus baru tetapi disajikan oleh satu spesies $C$. bonariensis yang memiliki distribusi terputus-putus yang terjadi di Amerika, Afrika dan Madagastar. Canavalia subgenus Wenderothia adalah subgenus terbaru sedangkan subgenus maunaloa terbatas di Hawai (Moteetee, 2016).

Koro pedang mampu tumbuh hingga 2000 meter dpl dengan kisaran suhu 20 - 32 ${ }^{\circ} \mathrm{C}$ di daerah tropik dan $14-27{ }^{\circ} \mathrm{C}$ di lahan tadah hujan, tumbuh baik pada daerah dengan curah hujan tinggi $4200 \mathrm{~mm} /$ tahun maupun tempat yang kering karena perakarannya dalam. Pertumbuhan yang optimal tanaman koro pedang bila mendapat sinar matahari penuh, tetapi pada tempat ternaungi masih mampu menghasilkan biji. Tanaman ini dapat tumbuh pada tekstur dan kesuburan tanah dengan kisaran luas (Pusat Penelitian dan Pengembangan Tanaman Pangan, 2017). Koro pedang memiliki keunggulan agronomis yang cocok untuk penanaman di daerah tropis dan hasil rata-rata sebanding dengan kacang kedelai (Ekanayake, et al., 2000). Biji koro pedang berpotensi sebagai sumber protein nabati untuk kebutuhan pangan dan pakan, ditinjau dari komposisi 
proksimat dan mineral dengan keseimbangan asam amino dan bioavailabilitas yang tinggi dan rendahnya antitripsin (Lukiwati dan Prawiradiputra, 2014).

Tanaman Koro bisa sebagai pengganti kedelai karena memiliki nilai gizi yang hampir sama dengan bahan kering $27,6 \%$ asfed untuk hijauannya (aerial). Kandungan zat-zat makanan \% bahan kering pada koro "Jack bean" (Canavalia ensiformis) bagian aerial (tajuk) adalah sebagai berikut: Protein kasar 19,1\%, Serat kasar 35,0\%, NDF 45,5\%, ADF 31,1\%, Lignin 10,3\%, Abu 9,4\%, ether extract 1,8\% Energi $18,7 \quad \mathrm{MJ} / \mathrm{kg} \quad \mathrm{BK}$. Kandungan mineralnya untuk Ca $24,4 \mathrm{~g} / \mathrm{kg} \mathrm{BK}$, Fosfor $2,6 \mathrm{~g} / \mathrm{kg} \mathrm{BK}$, Potassium 15,6 g/kg BK, Magnesium 6,3 g/kg BK (Feedipedia A programme by INRA,CIRAD, AFZ and FAO. 2012).

Bahan Kering bagian daunnya $21 \%$ asfed. Daun koro 'Jack bean' memiliki kandungan zat-zat makanan \% bahan kering sebagai berikut: Protein kasar 22,9\%, Serat kasar 34,3\%, NDF 35,7\%, ADF 27,1\%, Lignin 9,2\%, Abu 11,2\%, ether extract 2,2\% Energi 18,5 MJ/kg BK. Kandungan mineral daun koro pedang jack bean untuk $\mathrm{Ca} 26,8$ g/kg BK, P 3, 1 g/kg BK, Potassium 12,4 g/kg BK dan Magnesium 6,5 g/kg BK (Feedipedia A programme by INRA,CIRAD, AFZ and FAO. 2012).

Penggunaan pupuk yang efektif harus memenuhi beberapa kriteria yaitu dosis, macam, waktu, cara pemberian, dan harga. Tingginya harga pupuk anorganik yang beredar di masyarakat sering membuat petani enggan melakukan pemupukan sehingga pertumbuhan dan hasil tanamannyapun menjadi rendah. Pupuk urea merupakan pupuk anorganik yang merupakan proses rekayasa secara kimia, fisik dan atau biologis dan merupakan hasil industri atau pabrik pembuat pupuk (Dewanto, dkk., 2013). Pupuk urea berbentuk butir-butir kristal berwarna putih merupakan pupuk yang mudah larut dalam air dan sifatnya sangat mudah menghisap air (higroskopis), Pupuk urea mengandung unsur hara $\mathrm{N}$ sebesar $46 \%$ yang artinya setiap $100 \mathrm{~kg}$ mengandung $46 \mathrm{~kg}$ nitrogen, Moisture 0,5\%, Kadar Biuret 1\%, ukuran 1-3,35mm (Hidayah dkk, 2016). Pupuk anorganik merupakan jalan tercepat dan termudah dalam menangani masalah kebutuhan nutrisi tanaman karena sifatnya yang mudah terurai dan dapat langsung diserap oleh tanaman. Hal ini membuat petani bergantung pada pupuk anorganik. Ada beberapa kelemahan pupuk anorganik, yaitu harganya yang mahal dan menyebabkan pencemaran lingkungan jika diberikan tidak tepat dan berlebihan (Ramadhani, dkk. 2016).

Produksi tanaman legum tergantung pada kondisi lingkungan, dan ketersediaan unsur hara. Tanaman legum memiliki kelebihan sehingga penggunaan urea bisa lebih hemat. Selain mendapatkan unsur nitrogen yang berasal dari tanah juga dapat memfiksasi nitrogen dari udara dengan adanya bantuan nodul (bintil akar) yang bekerja sama dengan bakteri Rhizobium (Permanasari, dkk., 2014

Nitrogen memiliki peran sebagai penyusun enzim yang sangat besar peranannya dalam proses metabolisme tanaman namun relatif tidak tersedia bagi tanaman. Efisiensi pemakaian pupuk Nitrogen $(\mathrm{N})$ dapat dimaksimalkan dengan jalan 1) pemupukan tepat waktu, 2) menanam varietas unggul yang tanggap terhadap pemberian Nitrogen $(\mathrm{N})$, 3)memperbaiki teknik budidaya, 4) pengaturan waktu pemberian pupuk Nitrogen $(\mathrm{N})$ yang tepat selama musim tanam dengan Leaf Color Chart (LCC) atau Bagan Warna Daun (BWD) serta 5) pemupukan NPK secara bersamaan (Tando, 2018). Ketersediaan unsur hara pada proses metabolisme sangat berperan penting dalam pembentukan protein, enzim, hormon, dan karbohidrat, sehingga akan meningkatkan proses pembelahan sel pada jaringan-jaringan tanaman, proses tersebut akan berpengaruh pada pembentukan tunas, pertumbuhan akar dan daun, sehingga akan meningkatkan bobot brangkasan basah tanaman dan bobot brangkasan kering tanaman (Laksono, 2016).

Produksi tanaman yang dapat dicapai sangat bergantung pada pertumbuhan tanaman. Pertumbuhan tanaman merupakan 
suatu proses yang ditandai dengan bertambahnya ukuran dan berat tanaman. Penambahan tersebut disebabkan oleh bertambahnya ukuran organ tanaman seperti tinggi tanaman, diameter batang, dan luas daun sebagai akibat dari metabolisme tanaman. Produktivitas hijauan koro pedang menghasilkan hijauan segar untuk pakan dan bahan organik adalah sebesar 30-40 ton/ha (Purwanto, 2007). Produksi hijauan Canavalia gladiata cukup tinggi dibandingkan dengan produksi hjauan Canavlia virosa yaitu 31 ton/ha (Erna dkk, 2009).

Berdasarkan informasi tentang mudahnya tanaman koro pedang tumbuh serta pemanfaatannya yang luas, tanaman ini potensial untuk dikembangkan sebagai hijauan pakan ternak. Kandungan protein kasar pada hijauan Cavalia virosa sebesar $18.66 \%$ (Erna dkk, 2009). Koro pedang memiliki kandungan protein yang tinggi, serat kasar dan gizi lain sebanding dengan legum yang lain. Pemanfaatan dari komposisi protein kacang koro untuk pakan ternak akan mengurangi ketergantungan pada suplemen protein konvensional dan mampu dijadikan sebagai pakan sumber protein.

Kandungan Serat Kasar selalu berbanding terbalik dengan kandungan Protein Kasar suatu bahan pakan termasuk hijauan pakan. Kandungan Serat Kasar pada tanaman disebabkan terjadinya peningkatan bobot dinding sel dan menurunnya isi sel tanaman. Dinding sel lebih banyak disusun oleh selulosa dan hemiselulosa. Pemupukan nitrogen akan menurunkan kandungan serat kasar pada hijauan pakan (Seventri, dkk., 2018).

\section{METODE PENELITIAN}

\section{Objek dan Metode}

Penelitian dilakukan secara eksperimen di Laboratorium Tanaman makanan Ternak dan Laboratorium Nutrisi Ternak dan Bahan Kimia Pakan Ternak Fakultas Peternakan Universitas Padjadjaran. Rancangan Percobaan menggunakan
Rancangan Acak Lengkap (RAL). Percobaan dilakukan dengan 5 perlakuan dan masingmasing perlakuan diulang 4 kali sehingga di dapat 20 unit percobaan. Adapun perlakuan penelitian sebagai berikut:

$\mathrm{P} 0=$ Penggunaan $0 \mathrm{~kg} / \mathrm{ha}$ pupuk urea pada tanaman kacang koro pedang (kontrol)

$\mathrm{P} 1=$ Penggunaan $50 \mathrm{~kg} / \mathrm{ha}$ pupuk urea pada tanaman kacang koro pedang

$\mathrm{P} 2=$ Penggunaan $100 \mathrm{~kg} / \mathrm{ha}$ pupuk urea pada tanaman kacang koro pedang

$\mathrm{P} 3=$ Penggunaan $150 \mathrm{~kg} / \mathrm{ha}$ pupuk urea pada tanaman kacang koro pedang

P4= Penggunaan $200 \mathrm{~kg} / \mathrm{ha}$ pupuk urea pada tanaman kacang koro pedang

Lahan diolah dengan penambahan pupuk kandang dengan dosis 2,5 $\mathrm{kg}$ dan dicampur dengan $10 \mathrm{~kg}$ tanah. Kemudian dimasukkan kedalam polybag. Menimbang biji tanaman koro pedang dengan tujuan mendapatkan benih yang mendekati seragam. Biji koro pedang yang sudah ditimbang kemudian ditanam ke dalam polybag dengan kedalaman $\pm 2 \mathrm{~cm}$, ditanam 1 benih per polybag. Dilakukan penyiraman pada pagi dan sore, penyiraman dilakukan sampai umur panen. Setelah tanaman mencapai umur 1 bulan dilakukan pemupukan dengan dosis sesuai perlakuan.

\section{Respon yang Diukur}

1) Variabel Hasil Tanaman yang diukur

Berat segar hijauan koro pedang umur 4 bulan ditimbang segera setelah dilakukan pemotongan pada saat dipanen (g). Berat kering hijauan koro pedang umur 4 bulan ditimbang segera setelah berat kering stabil/tidak berubah (g).

2) Pengamatan kualitas hijauan tanaman: Protein kasar (\% BK) dan Serat kasar (\% BK)

\section{HASIL DAN PEMBAHASAN}

Analisis sidik ragam dilakukan untuk mengetahui pengaruh perlakuan terhadap berat segar hijauan koro pedang. Pemberian berbagai dosis pupuk urea pada hijauan koro pedang tidah memberikan pengaruh yang 
nyata $(\mathrm{P}>0,05)$. Hal ini diduga disebabkan oleh adanya bintil akar pada tanaman koro pedang, dengan adanyanya bintil akar pada koro pedang memiliki kemampuan dalam mengikat $\mathrm{N}$ di atsmosfir oleh bakteri Rhizobium pada bintil akar, sehingga koro pedang mampu memproduksi hijauan dengan baik tanpa pemberian pupuk. Oleh karena itu tanpa pemupukan koro pedang tetap dapat menghasilkan hijauan yang sama dengan yang diberi pupuk urea.

Hal tersebut sesuai dengan pendapat
Oleh karena itu tanpa pemupukan koro pedang tetap dapat menghasilkan hijauan yang sama dengan yang diberi pupuk urea. Hal tersebut sesuai dengan pendapat Fanindi dkk. (2009), yang menyatakan bahwa pemupukan tidak memberikan pengaruh yang nyata terhadap bobot segar tanaman kacang pintoi (Arachis pintoi). Hal ini disebabkan tanaman Kacang Pintoi mampu mengikat $\mathrm{N}$ dari udara, sehingga walaupun tanpa pemupukan menghasilkan produksi hijauan yang sama dengan tanaman kacang

Tabel 1. Rata-Rata Berat Segar dan Berat Kering Hijauan Koro Pedang pada Perlakuan Berbagai Dosis Pupuk Urea

\begin{tabular}{rlcc}
\hline \multicolumn{2}{c}{ Dosis Pupuk Urea } & $\begin{array}{c}\text { Berat Segar } \\
\text { (g/tanaman) }\end{array}$ & $\begin{array}{c}\text { Berat Kering } \\
\text { (g/tanaman) }\end{array}$ \\
\hline $0 \mathrm{~kg} / \mathrm{ha}$ & (P0) & $263,64 \mathrm{a}$ & $77,71 \mathrm{a}$ \\
$50 \mathrm{~kg} / \mathrm{ha}$ & (P1) & $335,44 \mathrm{a}$ & $80,95 \mathrm{a}$ \\
$100 \mathrm{~kg} / \mathrm{ha}$ & (P2) & $338,11 \mathrm{a}$ & $92,00 \mathrm{a}$ \\
$150 \mathrm{~kg} / \mathrm{ha}$ & (P3) & $465,85 \mathrm{a}$ & $92,23 \mathrm{a}$ \\
$200 \mathrm{~kg} / \mathrm{ha}$ & (P4) & $323,66 \mathrm{a}$ & $91,03 \mathrm{a}$ \\
\hline
\end{tabular}

Keterangan : Huruf yang sama pada kolom signifikasi menunjukan tidak berbeda nyata $(\mathrm{P}>0,05)$

Fanindi dkk. (2009), yang menyatakan bahwa pemupukan tidak memberikan pengaruh yang nyata terhadap bobot segar tanaman kacang pintoi (Arachis pintoi). Hal ini disebabkan tanaman Kacang Pintoi mampu mengikat $\mathrm{N}$ dari udara, sehingga walaupun tanpa pemupukan menghasilkan produksi hijauan yang sama dengan tanaman kacang pintoi yang diberi perlakuan pemupukan.

Analisis sidik ragam dilakukan untuk mengetahui pengaruh perlakuan terhadap berat segar hijauan koro pedang. Pemberian berbagai dosis pupuk urea pada hijauan koro pedang tidah memberikan pengaruh yang nyata $(\mathrm{P}>0,05)$. Hal ini diduga disebabkan oleh adanya bintil akar pada tanaman koro pedang, dengan adanyanya bintil akar pada koro pedang memiliki kemampuan dalam mengikat $\mathrm{N}$ di atsmosfir oleh bakteri Rhizobium pada bintil akar, sehingga koro pedang mampu memproduksi hijauan dengan baik tanpa pemberian pupuk. pintoi yang diberi perlakuan pemupukan.

Berat kering merupakan salah satu indikator paling baik dalam menentukan produktivitas tanaman. Berat kering hijauan adalah produksi hijauan tanpa air setelah dikeringkan secara alami maupun buatan. Berdasarkan hasil analisis ragam memperlihatkan pengaruh perlakuan terhadap berat kering hijauan koro pedang tidak berpengaruh nyata $(\mathrm{P}<0,05)$.

Hal ini diduga karena koro pedang merupak legum yang mampu menambat $\mathrm{N}$ dari udara oleh bakteri Rhizobium sehingga pemupukan urea dengan dosis rendah lebih cocok untuk dijadikan starter untuk pertumbuhan. Menurut Mulyadi (2012) pemupukan nitrogen atau urea pada legum, dapat meningkatkan $\mathrm{N}$ tersedia dalam tanah. Nitrogen yang diberikan dalam jumlah minimum dapat menyebabkan Rhizobium bekerja maksimum dalam menambat $\mathrm{N}$ udara, oleh karena itu pemberian sedikit pupuk nitrogen sangat dianjurkan sebagai 
starter supaya tanaman legum berumur muda memiliki kecukupan nitrogen sebelum Rhizobium bekerja dan menetap di akar tanaman. Menurut Permanasari dkk. (2014) pemberian perlakuan $0 \mathrm{~kg} / \mathrm{ha}, 75 \mathrm{~kg} / \mathrm{ha}$ dan $150 \mathrm{~kg} / \mathrm{ha}$ pupuk urea terhadap produksi berat kering tanaman dan bobot biji kacang kedelai tidak memberikan pengaruh yang nyata.

Pengaruh yang terjadi terhadap pemberian pupuk urea diduga nitrogen dapat membantu pembelahan sel yang terjadi saat tanaman akif tumbuh. Unsur nitrogen dapat menyediakan protein yang dibutuhkan saat pembelahan sel, dari hal tersebut pembelahan sel pada organ tanaman dapat efisisen dan pertumbuhan bagian tanaman seperti batang, daun, cabang dan bagian lainnya dapat tumbuh maksimal. Sehingga pemberian nitrogen dapat meningkatkan berat basah dan berat kering tanaman (Sauwibi dkk., 2011).

Berdasarkan hasil analisis ragam memperlihatkan pengaruh perlakuan terhadap kualitas protein kasar kacang koro berpengaruh nyata $(\mathrm{P}<0,05)$. Hasil uji jarak berganda duncan menunjukkan bahwa perlakuan P0-P4 berbeda nyata, hal ini terlihat bahwa kandungan protein semakin meningkat seiring dengan bertambahnya dosis pupuk urea, dibandingkan dengan tanpa pupuk urea. Hal ini sejalan dengan pendapat Purnomo dkk. (2004) mengungkapkan bahwa kandungan protein kasar pada $\mathrm{M}$. atropurpureum sebesar 15,01\%, dan $C$.
Penambahan nitrogen pada pemupukan kacang koro setiap perlakuan menyebabkan peningkatan rataan protein kasar yang nyata antara kontrol dengan perlakuan lainnya. Dilihat dari Tabel 2. perlakuan menghasilkan rataan protein kasar tertinggi pada perlakuan P4 yaitu $200 \mathrm{~kg}$ urea/ha dengan rataan kandungan protein kasar $31.31 \%$. Semakin banyak tingkat penambahan nitrogen yang ditambahkan pada pemupukan kacang koro maka akan meningkatkan kandungan protein kasar semakin tinggi. Dalam penelitian tersebut tanaman legum dapat memfiksasi nitrogen dari udara, maka pemupukan 50 $\mathrm{kg} / \mathrm{ha}$ urea yang menghasilkan kandungan protei kasar $27,13 \%$ sudah cukup tinggi sebagai sumber protein dan sangat menguntungkan karena hemat pupuk serta menjaga kesuburan tanaman dan media tanam. Menurut McIlroy (1972) pemberian level pemupukan $\mathrm{N}$ yang berbeda-beda dapat menyebabkan kadar protein yang berbedabeda pula. ). Fiksasi nitrogen simbiotik penting pada pertanian berkelanjutan untuk mengurangi penggunaan pupuk dan menjaga kelestarian lingkungan (Pamungkas dan Prasetya, 2017). Pada penelitian tanaman koro pedang memiliki kemampuan dalam memanfaatkan nitrogen di udara dengan fiksasi nitrogen yang dilakukan oleh bakteri rhizobium yang ditandai dengan nodul di akar (Indriani et al., 2019). Pada ruminansia, peran protein kasar merupakan salah satu

Tabel 2. Rata-Rata Protein Kasar dan Serat Kasar Hijauan Koro Pedang pada Perlakuan Berbagai Dosis Pupuk Urea

\begin{tabular}{|c|c|c|}
\hline Dosis Pupuk Urea & Protein Kasar (\%) & Serat Kasar (\%) \\
\hline $0 \mathrm{~kg} / \mathrm{ha} \quad(\mathrm{P} 0)$ & $25,67 \mathrm{a}$ & $20,50 \mathrm{c}$ \\
\hline $50 \mathrm{~kg} / \mathrm{ha}$ (P1) & $27,13 \mathrm{~b}$ & $20,56 \mathrm{c}$ \\
\hline $100 \mathrm{~kg} / \mathrm{ha} \quad(\mathrm{P} 2)$ & $28,50 \mathrm{c}$ & $18,70 \mathrm{~b}$ \\
\hline $150 \mathrm{~kg} / \mathrm{ha} \quad(\mathrm{P} 3)$ & $30,21 \mathrm{~d}$ & $16,38 \mathrm{a}$ \\
\hline $200 \mathrm{~kg} / \mathrm{ha}$ (P4) & $31,31 \mathrm{e}$ & $15,49 \mathrm{a}$ \\
\hline
\end{tabular}

Keterangan : Huruf yang berbeda pada kolom signifikasi menunjukan berbeda nyata $(\mathrm{P}<0,05)$

pubescens sebesar $15,31 \%$ pemberian pupuk urea $50 \mathrm{~kg} / \mathrm{ha}$ nampak menghasilkan kadar protein kasar lebih tinggi dibandingkan dengan tanpa pemberian pupuk urea. nutrien yang sangat penting bagi kehidupan dan pertumbuhannya. Protein kasar yang tercukupi untuk ruminansia menyebabkan ternak tersebut mampu menjalankan 
fungsinya dalam proses penguraian serat kasar yang berasal dari hijauan pakan sehingga tersedianya asam-asam amino bagi ternak tersebut (Rochana at al., 2016).

Adanya kecenderungan peningkatan kadar protein kasar dengan meningkatnya dosis pemberian pupuk urea disebabkan karena pupuk urea sangat penting untuk memperoleh kandungan protein kasar yang tinggi. hal ini sesuai dengan yang diungkapkan Schaffer (1996) nitrogen erat kaitannya dengan sintesis protein dan menurut Tjitrosomo (1993) unsur nitrogen merupakan komponen esensial dalam asam amino yang menjadi dasar pembentukan protein.

Analisis sidik ragam dilakukan untuk mengetahui pengaruh perlakuan terhadap kandungan serat kasar hijauan koro pedang. Hasil analisis sidik ragam menunjukkan bahwa perlakuan memberikan pengaruh yang nyata $(\mathrm{P}<0,05)$ terhadap kandungan serat kasar hijauan koro pedang.

Hasil uji jarak berganda Duncan menunjukan bahwa perlakuan tanpa pemupukan (P0) dan pemupukan urea 50 $\mathrm{kg} / \mathrm{ha}$ (P1) menghasilkan kandungan serat kasar hijauan koro pedang paling tinggi, masing-masing sebesar $20,50 \%$ dan $20,56 \%$ jika dibandingkan dengan perlakuan lainnya yaitu pemupukan urea $100 \mathrm{~kg} / \mathrm{ha}(\mathrm{P} 2), 150$ $\mathrm{kg} / \mathrm{ha}$ dan $200 \mathrm{~kg} / \mathrm{ha}$ masing-masing sebesar $18,71 \%, 16,38 \%$ dan $15,50 \%$. Pada nodul (bintil akar) terdapat Bakteri Rhizobium yang dapat memfiksasi nitrogen bebas di udara dan membentuk senyawa amonium (senyawa yang mengandung protein) yang akan diubah menjadi asam amino oleh nodul dan diedarkan keseluruh bagian tanaman. Sebaliknya Rhizobium memperoleh karbohidrat dari tumbuhan inangnya sebagai sumber bahan organik bagi pertumbuhannya (Indriani dkk., 2018). Fiksasi nitrogen yang dilakukan bakteri rhizobium pada tanaman legum menyebabkan tanaman legum dapat hidup dengan sedikit atau tanpa nitrogen yang ditambahkan ke dalam tanah. Pemupukan urea diperlukan sebagai starter atau saat pertumbuhan awal dan selanjutnya peran rhizobium membantu tanaman dalam memperoleh nitrogen. Sebaliknya jika ditambahkan pupuk urea maka kandungan serat kasar semakin menurun, hal tersebut dikarenakan peran nitrogen umumnya untuk pembentukan kandungan protein kasar. Hal tersebut sesuai dengan peenelitian Rochana et al. (2016) bahwa kandungan serat kasar berbanding terbalik dengan kandungan protein kasar, hal tersebut dapat dilihat pada tanaman pakan di dataran rendah mendapatkan radiasi matahari penuh sehingga kandungan serat kasar lebih besar yang merupakan pembentuk energi bagi tanaman sedangkan kandungan protein kasar menurun.

Tanaman legum koro pedang dapat menambah sumber nitrogen yang murah sehingga membantu mengurangi biaya produksi, mengingat pupuk anorganik (urea) harganya semakin mahal dan penggunaan yang terus-menerus dapat mencemari lingkungan. Pemberian pupuk urea $50 \mathrm{~kg} / \mathrm{ha}$ sangat efisien untuk kandungan serat kasar dan protein kasar hijauan koro pedang.

\section{KESIMPULAN DAN SARAN}

Pemberian berbagai dosis pupuk urea memberikan hasil yang sama terhadap produksi berat segar dan berat kering hijauan koro pedang dan memberikan hasil yang berbeda terhadap kandungan protein kasar hijauan koro pedang. Pemupukan $50 \mathrm{~kg} / \mathrm{ha}$ pada koro pedang telah memenuhi syarat sumber hijauan ruminansia dengan kandungan protein kasar sebesar 27,13\%, kandungan serat kasar 20,56\%, hemat pupuk sintesis (anorganik), rhizobium dapat bekerja maksimal, kesuburan tanaman koro pedang dan tanah tetap terjaga.

\section{DAFTAR PUSTAKA}

Dewanto, F.G., J.J.M.R.Londok, R.A.V. Tuturoong dan W.B.Kaunang. 2013. Pemupukan anorganik dan organik terhadap produksi tanaman jagung sebagai sumber pakan. Jurnal Zootek. 32:158-171. 
Ekanayake, S., E.R.Jans and B.M.Nair. 2000.Literature review of an under ytilized legume: Canavalia gladiata L. Plant food for human nutrition. 55:305321.

Erna Winarti, Sarjiman, Supriyadi dan N. Cahyaningrum. 2009. Potensi Kerandang (Cavalia virosa) Sebagai Sumber Pangan dan Pakan Ternak Alternatif. Seminar nasional Teknologi Peternakan dan Veteriner. Balai pengkajian Teknologi Pertanian, Yogyakarta.

Fanindi, A., S.Yuhaeni, E. Sutedi dan Oyo. 2009. Produksi Hijauan dan Biji Leguminosa Arachis pintoi pada Berbagai Jenis Pemupukan. Prosiding Seminar Nasional Teknologi Peternakan dan Veteriner. Pusat Penelitian dan Pengembangan Peternakan.

Feedipedia A programme by INRA,CIRAD, AFZ and FAO. 2012. Jack bean (Canavalia ensiformis). https://www.feedipedia.org/node/327. Diakses pada tanggal 5 Oktober 2019.

Hidayah, U., P. Puspitorini, dan W.Agung Setya. 2016. Pengaruh pemberian pupuk urea dan pupuk kandang ayam terhadap pertumbuhan dan hasil tanaman jagung manis. Journal Viabel Pertanian. 10:1-19.

Indriani, N.P., H.K. Mustafa, B. Ayuningsih, Mansyur dan A.Rochana. 2018. Pengaruh pupuk Fosfor Terhadap Produksi Segar Tanaman Kacang Koro Pedang (Canavalia gladiata) Sebagai Pakan Hijauan. Prosiding Seminar Nasional Biologi (Semabio 3). Pusat Penelitian dan Penerbitan UIN SGD.Bandung. 12 April 2018. P.126129.

Indriani, N.P., H.K.Mustafa, B. Ayuningsih, Mansyur and A.Rochana.2019. Production and nitrogen, phosphorus and calcium absorption of swordbean leaf (Canavalia gladiata) in application of rock phosphate and VAM inoculation. Legume Research. 42(2):238-242.DOI:10.18805/LR-422.
Lukiwati, D.R., dan B.R. Prawiradiputra. 2014. Peluang Koro Pedang Sebagai Pangan, Paka dan Tanaman Obat. Prosiding Seminar Hasil Penelitian Tanaman Aneka Kacang dan Umbi. 908-916.

McIlroy, R.J. 1972. An Introduction to Tropical Grassland Husbandry Secon Ed. Oxfod University Press, Ely Haouse, London.

Moteetee, A.N. 2016. Canavalia (Phaseoleae, Fabaceae) species in South Africa: Naturalized and indigenous. South Africa Journal of Botany. 103:6-16.

Mulyadi, A. 2012. Pengaruh pemberian legin, Pupuk N P K (15:15:15) dan urea pada tanah gambut terhadap kandungan N,P total pucuk dan bintil akar kedelai (Glycine max (L.) Merr.). Kaunia. 3:21-29

Pamungkas, R.Y. dan B. Prasetya. 2017. Pemanfaatan bakteri penambat $\mathrm{N}$ sebagai pupuk hayati dan pengaruhnya terhadap serapan nitrogen tanaman kedelai pada Alfisol. Jurnal Tanah dan Sumberdaya Lahan. 4:533-541.

Permanasari I, M.Irfani dan Abizar. 2014. Pertumbuhan dan hasil kedelai (Glycine max L. Merril) dengan pemberian rhizobium dan pupuk urea pada media gambut. Jurnal Agroteknologi. 5:29-34.

Purnomo, J., E. Tuherkih , I-G.Putu Wigena dan E. Sutedi. 2004. Pengaruh Pemupukan Nitrogen Dan Belerang Terhadap Produksi Dan Kualitas Tanaman Pakan di Sumbawa, Nusa Tenggara Barat. Balai Penelitian Ternak. Seminar Nasional Teknologi Peternakan dan Veteriner, Bogor.

Purwanto. 2007. Metodologi Penelitian Kuantitatif. Pustaka Pelajar. Yogyakarta.

Pusat Penelitian dan Pengembangan Tanaman Pangan. 2007. Kelayakan dan Teknologi Budi daya Koro Pedang (Canavalia sp.) http://www.puslittan. bogor.net. Diakses 9 maret 2016.

Ramdhani, R.H., M.Raviq dan M.D. Maghfoer. 2016. Pengaruh sumber 
pupuk nitrogen dan waktu pemberian urea pada pada pertumbuhan dan hasil tanaman jagung manis (Zea mays Sturt.var.Saccharata). Jurnal Produksi Tanaman. 4:8-15.

Rochana, A., N.P.Indriani, B.Ayuningsih, I.Hernaman, T.Dhalika, D.Rahmat and S. Suryanah.2016. Feed forage and nutrition value at altitudes during the dry season in West Java. Anim. Prod. 18:85-93.

Sauwibi, D. Ali, M. Maryono dan F. Hendrayana. 2011. Pengaruh Pupuk Nitrogen Terhadap Pertumbuhan Dan Produktivitas Tembakau (Nicotiana tabacum L.) Varietas Prancak Pada Kepadatan Populasi 45.000/ha di Kabupaten Pamekasan Jawa Timur. Institut Teknologi Sepuluh Nopember : Surabaya

Schaffer A.A. 1996. Photoassimilate Distribution In Plant And Crops. Marcel Dekker. New York.

Seventri, O., S.Mulyani, dan Fridarti. 2018. Introduksi beberapa jenis leguminosa perdu dan pemberian pupuk urea terhadap produksi dan kualitas rumput lapangan. Jurnal Embrio. 10:1-14.

Tando, E. 2018. Review: Upaya efisiensi dan peninngkatan ketersediaan nitrogen dalam tanah serta serapan nitrogen pada tanaman padi sawah (Oriza sativa L.) Buana Sains. 18: 171-180.

Tjitrosomo, G. 1993. Taksonomi Umum (Dasar-dasar Taksonomi Tumbuhan). Yogyakarta: Gajah Mada University Press.

Winarti, E., Sarijiman., Supriyandi., dan C. Cahyaningrum. 2009. Potensi Kerandang (Canavalia Virosa) Sebagai Sumber Pakan Dan Pangan Ternak Alternatif. Balai Pengkajian Teknologi Pertanian, Yogyakarta. Seminar Nasional Teknologi Peternakan dan Veteriner: 765-769. 